\title{
Effect of Selection for Increasing Body Weight at Harvest on Immune Response Parameters in Second Generation of Nile Tilapia (Oreochromis Niloticus)
}

\author{
Emad M Zidan ${ }^{1}$ and Samy Y El-Zaeem ${ }^{2 *}$ \\ ${ }^{1}$ Faculty of Veterinary Medicine, Alexandria University, Egypt \\ ${ }^{2}$ Animal and Fish Production Department, Alexandria University, Egypt
}

Submission: May 08, 2019; Published: May 28, 2019

Corresponding author: Samy Y El-Zaeem, Animal and Fish Production Department, Faculty of Agriculture (Saba-Basha), Alexandria University, Egypt

\begin{abstract}
This paintings changed into carried out to analyze the impact of choice for expanded frame weight on immune reaction parameters in 2nd technology of Nile tilapia, Oreochromis niloticus through amassing 8 fish from decided on full-sib households and 8 fish from manage breed line. Blood samples had been gathered from the fish caudal peduncle of the 2 groups, and immune reaction parameters had been measured as overall protein, albumin, and globulin, ALT, AST, Urea, and creatinine, lysozyme activity, bactericidal activity, overall lipid, trigylcerol, overall cholesterol, and hematological parameters. The consequences discovered that the immune reaction parameters had been better in decided on breed line than manage breed line and this concluded that choice for expanded frame weight advanced immune reaction and capabilities which play a position in disorder resistance.
\end{abstract}

Keywords: Selection; Body weight; Immune; Oreochromis niloticus

\section{Introduction}

Selection for progressed immunity in carried out breeding applications can also additionally lower mortality costs in fish farming. The foundation for choice is genetic distinction in progressed quantitative tendencies along with immunity and disorder resistance [1]. Therefore, the price of selective breeding relies upon on the extent of genetic distinction to a disorder inside the populace in question, being maximum effective while the version is particularly massive [2].

Selection can be performed at once primarily based totally on survival facts beneath Neath farming conditions, in mission checks or circuitously the usage of correlated tendencies as indicators. As the immune device is frequently liable for cowl towards disorder, immunological markers are getting used as oblique measures of disorder resistance. The markers confirmed huge genetic distinction, correlate with disorder resistance in addition to being easy and brief to be quantified from massive populations of stay fish [3].

Both physiological and biochemical mechanisms conferring resistance to micro parasites will have a robust genetic foundation [4].

Previous paintings confirmed that capacity correlation exists among disorder resistance of fish and nonspecific immune parameters viz., serum lysozyme, complement, hemolytic, and bactericidal activities, which have an effect on inherent potential of fish to face up to pathogens previous to era of a particular immune response [5-9].

The objective of the existing research become to decide the specfic and non unique immune parameters among decided on and non- decided on breed line of the second one of full-sib Nile tilapia, Oreochromis niloticus.

\section{Material and Methods}

\section{Fish Origin and Culture Condition}

Nile tilapia used on these paintings became the second one era of choice application for growth. Sixteen fish have been randomly gathered from tanks (round fiber glass tanks with capability of 500 liter) and every tank represents a full-sib family. Sixteen fullsib households have been used. Eight fish have been gathered from decided on line, and the common frame weight became 35 \pm 1.five.

Also, 8 fish have been gathered from manipulate line, and their frame weights have been $28 \pm 1.1 \mathrm{~g}$. These tanks have been in laboratory at school of Veterinary Medicine, Alexandria University at duration from 30 September 2015 to 30 May 2016. At the cease 
of the experiment, blood samples have been gathered from the fish caudal peduncle of the 2 agencies and the subsequent parameters have been measured.

\section{Serum Samples}

Samples have been gathered with out anti-coagulant. Samples have been stored at room temperature for 15-20 min, with a purpose to clot then the clot is loosened from the wall and the tubes are located within side the incubator for $1 / 2$ of an hour to decorate retraction of the clot, then placed within side the fridge at $4 \mathrm{C}$ overnight, and the sera have been separated via way of means of centrifugation. The serum samples have been stored in deep freezer at 20-30C till being used [10].

\section{Clinico-Biochemical Analysis}

At the cease of the experiment, blood samples have been gathered from the fish caudal peduncle of the unique agencies. Adequate quantities of complete blood in small plastic vials containing heparin have been used for the dedication of hemoglobin $(\mathrm{Hb})$ via way of means of the usage of industrial kits (Diamond Diagnostic, Egypt) and the hematocrit (PCV $\%$ ) became measured in line with Stoskopf [11]. Also, general erythrocytes (RBCs), platelets and general leukocytes (WBCs) have been counted in line with Dacie \& Lewis [12] on an Ao Bright - Line Haemocytometer version (Neubauer improved, Precicolor HBG, Germany). Other blood samples have been gathered and transferred for centrifugation at $3500 \mathrm{rpm}$ for $15 \mathrm{~min}$ to gain blood plasma for dedication of general protein (TP) [13]; albumin (Al) [14]; globulin (Gl) via way of means of difference [15] and general ldl cholesterol [16] which have been assayed following industrial check kits the usage of a spectrophotometer (version 5010, Germany).

\section{Determination of (S. GOT) and (S. GPT)}

The pastime of serum aspartate aminotransferase (S. AST), commonly referred to as glutamic oxalacetic transaminase (S. GOT), and serum alanine aminotransferase (S. ALT), normally referred to as glutamic pyruvic transaminase (S. GPT), have been anticipated in line with Bohnert et al., [17] the usage of industrial kits made via way of means of Pasteur Lab. Estimation of serum alkaline phosphatase: Serum alkaline phosphatase became decide in line with changed approach of Aoki et al., [18] the usage of industrial kits produced via way of means of Pasteur Lab. Lysozyme pastime and Serum bactericidal pastime: Serum lysozyme pastime became anticipated via the turbidimetry defined via way of means of Hallmark et al., [19]. Serum bactericidal pastime to Aeromonas hydrophila stress (Standard stress ATCC acquired from Dept. Avian and aquatic Animal Med., Fac. Med. Alexandria University) became decided in line with Ranger and Rowley [20]. Determination of IgA, IgG and IgM Immunoglobulin an ELISA Kit (Saliva) - Sal metrics Assays, 1-1602. Chicken IgG ELISA Cat. No. KT-619 PRODUCT the K-ASSAY Ò Chicken IgG ELISA is an enzyme immunoassay for the quantitative dedication of IgG in hen serum plasma. Chicken IgM ELISA Cat. No. KT-621PRODUCT the K-ASSAY Ò Chicken IgM ELISA is an enzyme immunoassay for the quantitative dedication of IgM in hen serum plasma. IgM became measured in line with Ohta et al. [21], Nevens et al. [22] \& Wendelborn et al. [23].

\section{Total Cholesterol and Triglycerides Determination}

Cholesterol was estimated enzymatically in serum or plasma in a sequence of coupled reactions that hydrolyze cholesterol esters and oxidize the $3-\mathrm{OH}$ institution of ldl cholesterol. One of the response byproducts, $\mathrm{H} 2 \mathrm{O} 2$ became determined quantitatively in a peroxidase catalyzed response that produces a color. Absorbance became measured at $500 \mathrm{~nm}$.

Triglycerides became measured enzymatically in serum or plasma the usage of a sequence of coupled reactions wherein triglycerides are hydrolyzed to supply glycerol. Glycerol is then oxidized the usage of glycerol oxidase, and $\mathrm{H} 2 \mathrm{O} 2$, one of the response products, estimated as defined above for ldl cholesterol. Absorbance is measured at $500 \mathrm{~nm}$. High density lipoprotein (HDL) ldl cholesterol Low serum concentrations of HDL-ldl cholesterol became related to accelerated danger for CHD.

Coronary danger will increase markedly because the HDL awareness decreases from $40-$ to $30 \mathrm{mg} / \mathrm{dL}$. A low HDL-ldl cholesterol awareness became a fee beneath $35 \mathrm{mg} / \mathrm{dL}$, and excessive HDL, >60 mg/dL. HDL-ldl cholesterol values have been extensively utilized withinside the calculation of LDL-ldl cholesterol Low density lipoprotein (LDL) ldl cholesterol: Most of the circulating ldl cholesterol became observed in 3 primary lipoprotein fractions: very low-density lipoproteins (VLDL), LDL and HDL. $[$ Total chol $]=[$ VLDL-chol $]+[$ LDL-chol $]+[$ HDL-chol $]$. LDL-ldl cholesterol became calculated from measured values of general ldl cholesterol, triglycerides and HDL-ldl cholesterol in line with the relationship: [LDL-chol] $=[$ total chol $]-[\mathrm{HDL}-$ chol] - [TG] /five. (Bachorik and Albers 1986). Where [TG]/five anticipated of VLDL- ldl cholesterol and all values are expressed in $\mathrm{mg} / \mathrm{dL}$.

\section{Statistical Analysis}

Data have been analyzed via way of means of Student's " $t$ " check to evaluate the unique parameters the usage of SPSS (2010) statistical package deal version. The records values have been offered as mean \pm widespread mistakess of mean (SEM).

\section{Results and Discussion}

Mean values of immune parameters had been as compared among decided on bred line and non-decided on bred line of the second one technology of Nile tilapia, Oreochromis niloticus.

The maximum method of overall protein, albumin, globulin, alpha, beta, gama, ALT, AST, Total lipid, Triglycerol, cholesterol, HDL, LDL, Lysozyme activity, Bactericidal activity, IgA, IgG, IgM, TWBCS, TRBCS, HB, PCV, Lymphocytes, monocytes, Basophil, Eosinophil, Neutrophil, and Heterophil, confirmed large superiority for decided on bred line as compared to the ones of non-decided on bred line of Nile tilapia. While, the method of 
urea, creatinine, and Alkaline phosphate confirmed large lower for decided on bred line as compared to non-decided on bred line (Table1). Experimental choice for growing frame weight had a big and large impact on immune features. The consequences of choice for extended immune features are mixed, however. Significant standard impact became located.

Pinard-Van Der Laan [24] placed no regular difference most of the fingers of the immune system, each while comparing the effects of preference for growth on particular immune system components, or while comparing the effects of preference for growth on particular components of the immune system. This isn't unexpected because of the truth the effectiveness of diverse fingers of the immune system need now now not be genetically correlated. However, the effects of preference for growth have been regular with recognize to the factor of immune feature that turned into measured, even as the version in increase reaction to immune feature choice turned into unbiased of the form of immune reaction that turned into decided on. Variation in innate immune reaction turned into tested for fish amassed randomly from tanks. The decided on fish had been acquired from the second one era of choice software of Nile tilapia for increase confirmed widespread superiority in comparison to non-decided on bred line.

Table 1: Immune parameters (Mean \pm S.E) of the second generation of the selected and non-selected bred line of Nile tilapia, O. niloticus.

\begin{tabular}{|c|c|c|c|}
\hline \multirow{2}{*}{ Parameters } & \multicolumn{2}{|c|}{ Type of Breeding } & \multirow{2}{*}{ t-values } \\
\hline & Selected & Non-selected & \\
\hline Total protein & $6.38 \pm 0.09^{* * *}$ & $5.03 \pm 0.09$ & 11.17 \\
\hline Albumin & $3.38 \pm 0.09 * *$ & $2.48 \pm 0.13$ & 5.94 \\
\hline Globulin & $3.00 \pm 0.12^{*}$ & $2.55 \pm 0.10$ & 2.89 \\
\hline Alpha & $1.35 \pm 0.06^{* * *}$ & $0.80 \pm 0.04$ & 7.2 \\
\hline Beta & $1.50 \pm 0.11^{* *}$ & $0.83 \pm 0.05$ & 5.71 \\
\hline Gama & $2.85 \pm 0.13^{* *}$ & $1.63 \pm 0.05$ & 9.09 \\
\hline ALT & $65.75 \pm 0.63^{* *}$ & $54.25 \pm 1.65$ & 6.5 \\
\hline AST & $63.75 \pm 1.55^{* *}$ & $55.25 \pm 2.06$ & 3.3 \\
\hline Urea & $20.25 \pm 0.48$ & $23.50 \pm 0.65^{* *}$ & 4.04 \\
\hline Creatinine & $9.50 \pm 0.65$ & $15.50 \pm 1.04^{* *}$ & 4.89 \\
\hline Alkaline phosphate & $8.00 \pm 0.41$ & $11.25 \pm 0.48^{* *}$ & 5.16 \\
\hline Total lipid & $45.75 \pm 0.85^{* * *}$ & $40 \pm 0.40$ & 6.07 \\
\hline Triglycerol & $187.00 \pm 0.91^{* *}$ & $176.25 \pm 1.75$ & 5.44 \\
\hline Cholesterol & $211.75 \pm 1.25^{* * *}$ & $201.75 \pm 0.85$ & 6.6 \\
\hline HDL & $42.00 \pm 1.08^{* * *}$ & $33.50 \pm 0.65$ & 6.75 \\
\hline LDL & $104.25 \pm 1.25^{* * *}$ & $93.00 \pm 0.91$ & 7.26 \\
\hline Lysozyme activity & $15.75 \pm 0.85^{* *}$ & $10.25 \pm 0.48$ & 5.61 \\
\hline bactericidal activity & $43.50 \pm 1.50^{* * *}$ & $32.75 \pm 0.85$ & 6.22 \\
\hline IGA & $82.00 \pm 1.08^{* * *}$ & $70.50 \pm 0.65$ & 9.13 \\
\hline IGG & $981.00 \pm 1.47^{* * *}$ & $970.50 \pm 0.6$ & 6.53 \\
\hline IGM & $237.00 \pm 1.29^{* * *}$ & $223.50 \pm 1.19$ & 7.68 \\
\hline TWBCS & $28.00 \pm 0.91^{* *}$ & $16.50 \pm 1.18$ & 7.66 \\
\hline TRBCS & $18.25 \pm 0.48^{* * *}$ & $10.00 \pm 0.41$ & 13.11 \\
\hline $\mathrm{Hb}$ & $13.50 \pm 0.29^{* *}$ & $11.00 \pm 0.41$ & 5 \\
\hline PCV & $41.50 \pm 0.65^{* * *}$ & $31.50 \pm 0.65$ & 10.95 \\
\hline Lymphocytes \% & $46.50 \pm 0.65^{* * *}$ & $36.00 \pm 0.91$ & 9.39 \\
\hline Monocytes \% & $17.25 \pm 0.48^{* * *}$ & $11.25 \pm 0.48$ & 8.86 \\
\hline Basophil \% & $1.00 \pm 0.01^{* * *}$ & $0.18 \pm 0.05$ & 17.23 \\
\hline Eosinophil \% & $15.50 \pm 0.87^{* * *}$ & $8.75 \pm 0.85$ & 5.55 \\
\hline Neutrophil \% & $43.83 \pm 1.73^{* * *}$ & $19.75 \pm 1.49$ & 10.54 \\
\hline Heterophil \% & $28.00 \pm 0.71^{* * *}$ & $16.50 \pm 0.65$ & 12.01 \\
\hline
\end{tabular}

* Significant at $(P<0.05),{ }^{* *}$ Significant at $(P<0.01),{ }^{* * *}$ Significant at $(P<0.001)$ 
El-Zaeem [25], stated that serum overall protein and globulin of genetically changed Tilapia zillii have been appreciably stronger as compared to non-genetically changed fish. Moreover El-Zaeem \& Assem [26] and Assem \& El-Zaeem [27], said that serum overall protein, globulin and IgM of each genetically changed Oreochromis niloticus and Tilapia zillii have been advanced appreciably as compared to non-genetically changed fish. The outcomes of the existing paintings are constant with those findings. RBC and WBC ranges have been stronger, and there has been additionally version in $\mathrm{Hb}$ and PCV ranges among decided on breed line and manipulate breed line. The quantities of hemoglobin and hematocrit are a characteristic of RBC changes [28]. Previous research have additionally stated that fish decided on for extended frame weight display extended WBC and $\mathrm{RBC}$ ranges and the cell innate immune reaction is stronger [29]. Selected breed line fish display a widespread boom in ldl cholesterol and triglyceride ranges as compared to non-decided on breed line. In the opposite Wang et al., [30] stated declining sample of triglycerides and overall serum levels of cholesterol in tilapia fed with feed containing Bacillus cereus. However, ranges of overall protein have been appreciably better in decided on breed line fish as compared to the manipulate breed line fish. In general, an boom in serum protein stage is a hallmark of innate immunity, that is taken into consideration vital in invertebrates and a essential protection mechanism of fish [31]. Such

mechanisms shape a chain of vital capabilities that preserve host cells alive, healthy, and guarded from pathogens [32]. The liver enzymes of ALT and AST extended in decided on breed line fish institution as compared to the manipulate line. This is according with the outcomes of Lin \& Luo [33].

Among the innate immune parameters, lysozyme interest become determined to upward push appreciably withinside the decided on fish as compared to the manipulate. Similar outcomes have been found withinside the look at of Mohapatra et al., Bandyopadhyay et al., [34,35]. Lysozyme is determined in fish mucus, serum and ova, which allows in degrading peptidoglycan layer of the cellular wall of bacteria. It additionally promotes phagocytosis through activitating polymorphonuclear leucocytes and macrophages. The highly huge version found withinside the ranges of lysozyme in decided on and manipulate bred line displays the version of their cappotential to destory bacteria. Such version in lysozyme ranges become additionally found in Atlantic salmon and rainbow trout through Roed et al., [5,7] decided on for ailment resistance. The enhancement of immune reaction parameters with choice breeding software reduced mortality charge in Nile tilapia there through shielding the fish in opposition to one of a kind illnesses through growing the immunity of fish. For our evaluation we determined usable statistics for fish choice traces, however statistics from different taxa do imply that choice for manufacturing tendencies had negative consequences on metabolic, duplicate and fitness tendencies [36]. Furthermore, productiveness and immune characteristic have been negatively related in sheep and pigs $[37,38]$. Studies concerning industrial fowl traces have been excluded from our analyses due to the fact the choice standards are unknown and manipulate traces are absent, however their outcomes help our findings. Modern industrial broilers had a reduced humoral reaction as compared with older, lighter traces [39]. Furthermore, variations stated among broiler and layer fowl traces are constant with our outcomes. A comparative look at among a broiler and a layer line counseled that broilers are greater specialised in mounting sturdy shorttime period humoral immune responses, even as layers appoint in a long-time period humoral immune and cell reaction. The impact of choice for immune characteristic on increase differed among choice traces, even as there has been no widespread usual impact.

This contrasts with the consequences of choice for increase on immune characteristic, which have been uniform throughout choice traces and immune tendencies. There are numerous viable causes for the distinction in outcomes among choice for increase or immune characteristic, which aren't collectively exclusive. First, the expenses of increase are probable to be excessive in contrast to immune characteristic [40].

Therefore, while increase is chosen for, there's probable to be much less leeway while as compared with choice for a much less aid disturbing procedure including immune characteristic, and this asymmetry may also purpose the one of a kind choice impact. The ability impact of an boom

in immune characteristic on increase is notably smaller than the ability impact of an boom in increase on immune

characteristic, which may also give an explanation for why choice for increase affected immune characteristic even as choice for immune characteristic did now no longer have an effect on increase. Secondly, due to the fact choice become for unmarried immune tendencies as opposed to for a greater complete degree of immune characteristic. It is viable that the choice achievement become completed on the price of different fingers of the immune system, or thru the choice of a greater unique reaction. In this manner it's miles viable that deciding on for an boom in additives of immune characteristic did now no longer bring about an boom withinside the aid allocation to all of the immune characteristic, and as a result no impact on increase [41-44].

\section{Conclusion}

In choice for multiplied frame weight of Nile tilapia at harvest multiplied immune reaction parameters in decided on breed line than non-decided on breed line, and this play critical function in disorder resistance and enhance immunity towards diseases.

\section{References}

1. Fjalestad KT, Carr WH, Lotz J, Sweeney JN and Gjedrem T (1999) Genetic variation and selection response in body weight and disease resistance in Pacific white shrimp (Penaeus vannamei). Aquaculture 204: 198.

2. Marsden M J, Freeman L C, Cox D and Secombes CJ (1996) Nonspecific immune responses in families of Atlantic salmon, exhibiting differential resistance to furunculosis. Aquaculture 146: 1-16. 
3. Lund T, Gjedrem T, Bentsen HB, Eide DM, Larsen HJS, et al. (1995) Genetic variation in immune parameters and association to survival in Atlantic salmon. J Fish Biol 46: 748-758.

4. Chevassus B and Dorson M (1990) Genetics of resistance to disease in fishes. Aquaculture 85: 83-107.

5. Roed KH, Larsen HJS, Linder RD and Refstie T (1993a) Genetic variation in lysozyme activity in rainbow trout. Aquaculture 109: 237-244.

6. Roed KH, Brun E, Larsen HJ and Refstie T, (1990) The genetic influence on serum hemolytic activity in rainbow trout. Aquaculture 85: 109 117.

7. Roed KH, Fjalestad KT and Stromsheim A (1993b) Genetic variation in lysozyme activity and spontaneous hemolytic activity in Atlantic salmon. Aquaculture 114: 19-31.

8. Roed KH, Brun E, Larsen H J and Refstie T (1992) Genetic variation in serum hemolytic activity in Atlantic salmon. Fish Biol 40: 739-750.

9. Sarder MRI, Thompson KD, Penman DJ and MacAndrew BJ (2001) Immune responses in Nile tilapia clones: Non- specific responses. Dev. Comp Immunol 25(1): 37-46

10. Lied E, Gezerde Z and Braskhan DR (1986) Simple and rapid technique for repeated blood sampling in Rainbow trout. J of Fish Res Board of Canada 32 (5): 699-701.

11. Stoskopf MK (1993) Fish Medicine. In: WB Saunders Comp, Philadelphia, US.

12. Dacie JV and Lewis SM (1995) Practical Haematology. In: $8^{\text {th }}$ (edn.), Churchill Livingston, Scotland, US.

13. Gornall AG, Bardawill GJ and Parid MM (1949) Method of determination protein in serum blood. J Biol Chem 177: 751.

14. Weichsebum TE (1946) Method for determination of albumin in serum blood. Amer J Clin Pathol 16-40.

15. Doumas BT and Biggs HG (1972) Determination of serum albumin Standard Method of Clinical Chemistry 7: 175-188.

16. Ellefson RD and Caraway WT (1976) Fundamentals of clinical chemistry. In: Tietz NW (ed.), p. 506.

17. Bohnert M, Baumgartner R and Pollak S (2000) Spectrophotometric evaluation of the colour of intra- and subcutaneous bruises. Int J Legal Med 113(6): 343-384.

18. Aoki T, Arai T and Egusa S (1977) Detection of R plasmids in naturally occurring fish-pathogenic bacteria, Enterobactereacea. Microbial Immunol 21 (2): 77-83.

19. Hultmark D, Engström A, Andersson K, Steiner H, Bennich H, Boman H G (1983) Insect immunity. Attacins, a family of antibacterial proteins from Hyalophora cecropia. The EMBO Journal 2(4): 571-576.

20. Rainger G E and Rowley A F (1993) Antibacterial activity in the serum and mucus of rainbow trout, Oncorhynchus mykiss, following immunisation with Aeromonas salmonicida. Fish \& Shellfish Immunology 3(6): 475-482.

21. Ohta M, Okada M, Yamashina I, Kawasaki T (1990) The Mechanism ofcarbohydrate-mediated complement activation by the serummannan-binding protein. J Biol Chem 265: 1980-1984.

22. Nevens JR, Mallia AK, Wendt MW, Smith PK (1992) Affinitychromatographic purification of immunoglobulin M antibodies utilizingimmobilized mannan binding protein. J Chrom 597(1-2): 247 256

23. Wendelborn LA, Sommer CV, Larson CS, Nevens JR (1992) Purification of fish IgM using mannan-binding protein affinitychromatography. Poster presentation at the Autumn ImmunologyConference, Chicago, USA.
24. Pinard-van der Laan MH (2002) Immune modulation: the genetic approach. Veterinary Immunology and Immunopathology 87: 199205.

25. El-Zaeem SY (2001) Breeding studies in Tilapia, Faculty of Agriculture (Saba-Basha), Alexandria University, Egypt.

26. El-Zaeem SY, Assem SS (2004) Application of Biotechnology in fish breeding: II. production of highly immune genetically modified Nile Tilapia, Oreochromis niloticus with accelerated growth by direct injection of shark DNA into skeletal muscles. Egypt J Aquat Biol Fish 8(3): 67-92.

27. Assem SS, El-Zaeem SY (2005) Application of biotechnology in fish breeding: II. Production of highly immune genetically modified redbelly tilapia, Tilapia zillii. Afr J Biotechnol 5: 449-459.

28. Soltanzadeh S, Esmaeili Fereidouni A, Ouraji H (2016) Growth performance, body composition, hematological, and serum biochemical responses of beluga (Huso huso) juveniles to different dietary inclusion levels of faba bean (Vicia faba) meal. Aquacult Int 24(1): 395-413

29. Kumar R, Mukherjee SC, Prasad KP and Pal AK (2006) Evaluation of Bacillus subtilis as a probiotic to Indian major carp Labeo rohita (Ham.). Aquaculture Res 37: 1215-1221.

30. Wang M, Liu G, Lu M, Ke X, Liu Z, Gao F, et al. (2016) Effect of Bacillus cereus as a water or feed additive on the gut microbiota and immunological parameters of Nile tilapia. Aquac Res 48(6): 31633173.

31. Ellis AE (1990) Lysozyme assays. In: JS Stolen, TC Fletcher, DP Anderson, BS Roberson and Van WB Muiswinkel (eds.) Techniques in fish Immunology, SOS Publications, Bangladesh pp. 101-103.

32. Kamgar M and Ghane M (2012) Evaluation of Bacillus subtilis effect as probiotic on Hematological parameters of rainbow Trout, Oncorhynchus mykiss (INaIbaum) following experimental infection with Streptococcus iniae. J Fish Aquat Sci 7: 422-430.

33. Lin S and Luo L (2011) Effects of different levels of soybean meal inclusion in replacement for fish meal on growth, digestive enzymes and transaminase activities in practical diets for juvenile tilapia, Oreochromis niloticus $\times$ 0. aureus. Anim Feed Sci Technol, 168(1): 8087.

34. Mohapatra S, Chakraborty T, Prusty AK, PaniPrasad K and Mohanta KN (2014) Beneficial Effects of Dietary Probiotics Mixture on HematoImmunology and Cell Apoptosis of Labeo rohita Fingerlings Reared at Higher Water Temperatures. PLoS ONE 9(6): e100929.

35. Bandyopadhyay P, Sarkar B, Mahanty A, Rathore RM and BC Patra (2015) Dietary Administered Bacillus sp. PP9 Enhances Growth, Nutrition and Immunity in Cirrhinus mrigala (Hamilton). Proc Natl Acad Sci India Sect B Biol Sci 85(3): 759-766.

36. Rauw WM, Kanis E, Noordhuizen-Stassen EN and Grommers FJ (1998) Undesirable side effects of selection for high production efficiency in farm animals: a review. Livestock Production Science 56: 15-33.

37. Clapperton M, Glass EJ and Bishop SC (2008) Pig peripheral blood mononuclear leucocyte subsets are heritable and genetically correlated with performance. Animal 2(11): 1575-1584.

38. Greer AW (2008) Trade-offs and benefits: implications of promoting a strong immunity to gastrointestinal parasites in sheep. Parasite Immunology 30(2): 123-132.

39. Kramer J, Visscher AH, Wagenaar JA, Cornelissen J and Jeurissen SHM (2003) Comparison of natural resistance in seven genetic groups of meat-type chicken. British Poultry Science 44: 577-585.

40. Klasing KC (1998) Nutritional modulation of resistance to infectious diseases. Poultry Science 77: 1119-1125. 
41. Wijga S, Parmentier HK, Nieuwland MGB and Bovenhuis H (2009) Genetic parameters for levels of natural antibodies in chicken lines divergently selected for specific antibody response. Poultry Science 88: 1805-1810.

42. Bachorik PS, Albers JJ (1986) Precipitation methods for quantification of lipoproteins. Methods Enzymol 129: 78-100.
43. Diab AS, John G, Abd El Hady Y and Fathy M (2004) Evaluation of Nigella Sativa L. (Black Seeds, Barka), Allium Sativum (Garlic) \& Blogen as feed additives in Fish cluture O. niloticus. SCMJ 2: 557-562.

44. FAO (2005) Aquaculture production, Yearbook of Fishery Statistics. Food and Agriculture organization of the United Nations, Rome, Italy.

\section{Your next submission with Juniper Publishers will reach you the below assets}

- Quality Editorial service

- Swift Peer Review

- Reprints availability

- E-prints Service

- Manuscript Podcast for convenient understanding

- Global attainment for your research

- Manuscript accessibility in different formats

( Pdf, E-pub, Full Text, Audio)

- Unceasing customer service

Track the below URL for one-step submission https://juniperpublishers.com/online-submission.php 